\title{
Influence of Participatory Project Initiation on Sustainable Forest Management in Saboti, Trans-Nzoia County, Kenya
}

\author{
Anthony Tabot $\mathbb{D}^{\mathrm{D}}$, Ochieng Owuor, and Joash Migosi \\ University of Nairobi, Nairobi, Kenya \\ Correspondence should be addressed to Anthony Tabot; tabot.tabot@gmail.com
}

Received 11 December 2019; Revised 8 June 2020; Accepted 18 June 2020; Published 15 July 2020

Academic Editor: Nikolaos D. Hasanagas

Copyright (C) 2020 Anthony Tabot et al. This is an open access article distributed under the Creative Commons Attribution License, which permits unrestricted use, distribution, and reproduction in any medium, provided the original work is properly cited.

\begin{abstract}
Forestry related projects fail due to the lack of participation by the community during the initiation stage. This further leads to unsustainable management of forests. This study was undertaken to examine how participatory project initiation influences sustainable forest management in Saboti forest in Trans-Nzoia County, Kenya. Participatory Development Theory guided this study. The explanatory research design was adopted. The target population was 2600 community forest association (CFA) members and 15 Kenya Forest Officers. Census sampling was used in the sampling of Kenya forest Officers and simple random sampling to select community forest management members. The sample size was 347 community forest management members and 15 Kenya forest Officers. Data were collected using questionnaires and through interview. Data were analyzed using descriptive and inferential statistics. Presentation of findings was carried out using tables. There was a significant influence of participatory project initiation on sustainable forest management (SFM) $(r=0.700, p=0.00)$. This implies that an increase in participatory project initiation improved sustainable forest management in Saboti. Participatory project initiation had a significant influence on sustainable forest management. The community participation in initiation had a significant influence on sustainable forest management. There is need for forest management to involve the community members during the initiation stage of the projects in order to achieve sustainable forest management.
\end{abstract}

\section{Introduction}

Forests have a cultural, social, economic, and ecological value that play a crucial role in enhancing the quality of life and supporting natural systems in the environment. The various user groups, including herdsmen, hunters, firewood, and pole collectors, benefit from exploiting forest resources in different ecosystems [1]. Benefits accrued from the forest resource enable the community to appreciate that resource and use it sustainably.

It is advantageous to engage the community in order to sustainably manage the forest resource [2], by allowing individual forest users to participate in decision-making [3]. Use of local people in forest resources is beneficial when there is ownership of the decisions made as stated by decentralization theory [4]. A conducive environment for policy implementation through community participation is required [5].

There was a need for community participation in forest management [6] as the top-down approach inadequacies to community development are meant to be corrected by community participation [7]. Adesida and Okunlola [8] assert that the basis of community-based development initiatives consisted of the involvement of the community in project design and implementation. An enabling environment for sustainability is created through community participation by allowing users to decide on the level of services to pay, to guide essential investment and management decisions, and to entrust resources in support of these choices.

Most studies on factors touching on community participation activities have focused on population characteristics and social and economic factors that affect forestry management [9-11] and not their influence on sustainable management of forests, This paper seeks to bridge the knowledge gap.

In Tanzania, the enactment of the Forest Act of 2004 paved the way for the introduction of Participatory Forest Management (PFM). Under the provisions of this Act, communities residing adjacent to forests have ownership 
rights and power to share benefits accruing from forest conservation and management efforts with the Tanzanian government and other involved parties [12]. Effects of local participation in forest management are highly contested throughout the literature, and thorough studies showing causal-effects between community participation in forest management and positive outcomes are insufficient [13].

The Government of Kenya took knowledge of this new development in setting the stage for new forest management policy and the enactment of Forest Act 2005. The Act recognizes community involvement in forest conservation and livelihood improvement. A study conducted by the Research Action in 2009 affirms that the first pilot study on the impact of PFM through Community Forest Associations (CFAs) on poverty reduction was conducted in 1997 at Dida in Arabuko-Sokoke, Coast region [14].

1.1. Statement of the Problem. Under the PFM arrangement, the Community Forest Associations (CFAs) are empowered to carry out various management activities in forest preservation, while the actual access to decision-making processes, allocation of benefits, and the control of forests are entrusted to the Kenya Forest Service (KFS) $[15,16]$. Empirical studies have revealed that the CFAs under the PFM approach have played an indispensable role in enhancing forestry conservation practices in various water catchment towers, including the Mau complex, Kakamega forest, and Arabuko-Sokoke.

Ongugo [17] conducted a study on the roles of CFAs in the decentralization process of the Kenyan forests. In 2009, he performed a comparative analysis study on resource conservation outcome (under the National park and Forest reserve regime) in the Mount Elgon ecosystem and established that a flexible and community-involving system is more effective than a rigid and community-excluding system in managing forest resources.

Despite the establishment and existence of CFAs in the forest, cases of illegal logging, grazing, and forest encroachment remain high in the area and, hence, aggravate forest destruction in the Mount Elgon ecosystem. This raises a concern to the extent to which the integration of community participation promotes effective forest governance. Additionally, most of the empirical studies have focused on the impact of community forest associations- (CFAs) on forestry management on major water catchment towers such as the Mau Complex, Kakamega Forest, and ArabukoSokoke [17]. Still, no study has been conducted to examine the influence of community participation during initiation of programmes on sustainable forest management in a relatively smaller forest area such as Saboti forest [17]. There was a need to determine how participatory project initiation influences sustainable forest management in Saboti forest in Trans-Nzoia County.

\section{Literature}

2.1. Sustainable Forest Management. Communities are projected to have a role in the management of almost onethird of the world's forest area [18]. SFM has continued to evolve since 1992 and has encouraged changes in forest policy, legislation, and managerial practices around the world in keeping with the Forest Principles and Ecosystem Approach. In many countries, public participation is growing and wider forest management strategies have increased $[19,20]$. The findings are also more broadly accepted and implemented. Consequently, sustainable growth relies on capacity building.

The promotion of PFM, as well as training, on environmentally sound technological innovations and on biodiversity conservation tools [21] is another communal capacity building activity. Search for alternative livelihoods seeks to support sustainable livelihoods for adjacent forest communities in a sound governance framework. This governance system covers land preparation and the mapping of land resources by defining sensitive areas, integrated forestry management, integrated forestry enforcement, and protection of the environment.

The neighboring towns can learn how infrastructure investment and village-level development create opportunities for rural economic growth without any donor intervention during these coordinated support workshops [18]. PFM includes a shared agreed plan that defines the functions, responsibilities, powers, and benefits of governmental and community bodies in order to promote sustainable forest resource management and conservation.

2.2. Community Participation. According to [22], community participation in forest management has always been encouraged due to the tangible and intangible benefits the community gets from the forest. World Bank [1] defined participation as a method by which stakeholders impact development initiatives [23]. Warah [24] describes forest management as a participatory method, in which interested parties agree to that sets out their positions, advantages, obligation, and authority for forest resource management and use [25].

The Indian government introduced the National Joint Forest Management in 1990, which gave communities greater responsibility, power, and rights in the management of public forests Maharjan [26] in order to support their role in forest management further. Adhikari et al. [27] found that assets management and opportunities under the Nepalese Community Forests Program are inadequate for people to participate effectively.

Adhikari et al., [27] stated that due to sociocultural norms, greater capacity, and direct access to wealth, the higher financial benefits resulting from forest products $[28,29]$ in Ethiopia encouraged households to participate. Guthiga [30] has shown that sustainable forest management can be implemented by incorporation of community participation into decision-making, organizing and implementing processes in the region of Ampa in Nigeria, on the level of community involvement in conserving natural resources. The concept of involving communities in decision-making and implementing systems tends to improve environmental ethics, as societies understand that they live in the world [31]. 
Tanzania has integrated communities in forest management for many years, but under small-scale arrangement.

A study conducted by Iddi [12] on community participation in forestry management in Tanzania proposed that the local groups protect and maintain some of the forests in Kilimanjaro, Rukwa, and Shinyanga. The researchers also found that community-driven forests are best supported and effectively managed by the communities concerned. Kenya has a vibrant forest sector, which plays a key role in supporting economic development and growth. For many years, Kenya has, like other developing countries, experienced high level of forest destruction and environmental degradation, a trend that forced the government to develop effective strategies for restoring the industry. In 2008, Kenya was highly affected by a lack of coherent and appropriate forest policy that enabled communities to actively participate in forestry management programmes, according to [14].

The first case study on the role of communities in forest management through CFAs in 1997 was carried out, according to [25], on the impact of PFM on their livelihoods in the Arabuko Sokoke Forest. The investigators also found out that, but that the neighboring communities were forced to do so, and the government did not intend to engage the community in the forestry management of Arabuko-Sokoke. The problem of forest destruction and environmental degradation was fueled by the lack of effective forest policies and legislation which fostered conflict between local community and state bodies as the forest resources were scarce.

2.3. Participatory Project Initiation. The first phase of a project's life cycle is the initiation process. The needs and objectives of the project are identified throughout this phase. Community members have a better understanding of their issues and may, therefore, lead to finding a sustainable solution. The engagement of community members in the initiation process is important as the project should be focused on the community's needs [32].

The initiation of the project involves the need for assessment, project objectives selection, project teams, and other key project requirements. This is an important project step because it defines the project's progress and sustainability. According to Ehigiator [33], project startup participation helps the project team select the most appropriate intervention of the community. During this stage, the public participate in assessing their needs, where interventions are developed and selected.

A study conducted by Titus [29] on the level of community participation in the conservation of natural resource in Akampa area, Nigeria, affirms that sustainable forest management can be realized through integration of community participation in decision-making, organization, and implementation processes.

Maraga et al. [32] researched community involvement in project life activities in the Nyando basin in Kenya River.

2.4. Theoretical Framework. The participatory development theory is adopted in this study [34]. A growth definition, aligned with a western view of success, was introduced in the strategic model. Participatory theorists and practitioners needed to develop sensitivities to cultural diversity and other particular issues that globalization theorists neglected. The lack of sensitivity has been the cause of many projects' difficulties and delays [35]. Participatory development theory considers development to be a process focusing on community participation in the self-development of the communities using available resources to guide their future development. An individual's interests never conflict with those of a group. This approach focuses on the idea of capacity building, sustainability, and selfsufficiency.

The key principle of participatory collective development approaches is that, from the beginning of the selection of projects, all participants participate in development activities as priority, planning, implementation, evaluation, and surveillance. It also aims to protect property ownership and feasibility of services [36]. The society is a good way to achieve sustainable development by engagement in decisionmaking and solving issues. This research demonstrated clearly that the community development participatory approach is useful at the grassroots level of sustainable development.

\section{Methodology}

This study adopted an explanatory research design. The explanatory research design is quantitative in nature, and hypothesis is tested by measuring the relationships between variables, and data are analyzed using statistical techniques. The target population comprised the 2600 members of the Saboti-Sosio Community Forest Association and 15 staff working in the Saboti forest station. Yamane's [37] formula was used to get a sample size of CFA members. From the target population of 2600 community members, a sample size of 347 respondents was selected. With regard to the KFS staff, a sample size 15 was used.

The study utilized census sampling techniques to select all the KFS staff working with the Saboti forest station. Simple random sampling was used to select the 347 community members. The sampling unit was members of the Saboti-Sosio Community Forest Association. Primary data were collected using both questionnaires and interviews. Unless otherwise stated, all variables were measured on a 5 -point Likert scales anchored by $1=$ strongly disagree/very dissatisfied to $5=$ strongly agree/very satisfied. The respondents were asked to indicate the extent to which they agree or disagree with various statements. The questionnaire was designed to address the specific objectives.

The interview guide contained semistructured questions that are based on the research questions. Piloting was conducted in the Kiptogot Forest Station. The study utilized content validity. Cronbach's coefficient alpha was used to determine the reliability. Cronbach's alpha coefficient of 0.743 was obtained [38]. After all data have been collected, coding was performed for analysis using the Statistical Package for Social Sciences (SPSS V23). Descriptive statistics and Pearson product correlation were used. 


\section{Results}

4.1. Participatory Project Initiation. The study sought to establish how participatory project initiation influences forest management sustainably. The respondent's views on participatory project initiation were sought using means and standard deviations. A total of 7 statements were used to determine the participatory project initiation on a 5-point likert scale as presented in Table 1.

Majority of the respondents agreed that there was public participation during needs assessment $(M=4.092$; $\mathrm{SD}=1.229)$; management objectives were clearly described $(M=4.293 ; \mathrm{SD}=0.922)$, and the objectives were clearly stated based on functions of the forests, $(M=4.228$; $\mathrm{SD}=0.963)$. Most of the respondents agreed that committee members were a representation of local diversity $(M=4.194$; $\mathrm{SD}=0.995)$, and the contribution of all stakeholders was respected $(M=3.884 ; \mathrm{SD}=1.223)$. The findings agreed that stakeholders' interests were recognized $(M=4.208$; $\mathrm{SD}=1.130)$ and the baseline studies were conducted with consultation during development of PFMP $(M=3.946$; $\mathrm{SD}=1.196)$, from the seven statements used to explain participatory project initiation $(M=4.121$; $\mathrm{SD}=0.882) \mathrm{im}-$ plying that community members agreed with participatory project initiation in Saboti forest.

During the interview, one of the forestry officers stated that "Meetings are held during the initiation stage of a project or management plan development. All members of the community are invited. The community gives ideas which are deliberated upon in order to come to an agreement of what are the most preferred ideas to be incorporated in the plan. The community identifies the gaps and intervention required in a participatory manner. The community also assists in giving baseline information for planning purposes."

On the participatory project initiation, the findings indicated that there was public participation during needs assessment and management objectives clearly described. The objectives of initiation were clearly stated basing on functions of the forests. The committee members are a representation of local diversity, and stakeholders were mutually respected. The management always recognizes the legitimate interests of stakeholders, and baseline studies are conducted with consultation during the development of PFMP.

Ehigiator [33] agreed with these findings that the initiation of a project involves assessment of needs, project objective selection, project team, and other critical project requirements. The project's progress and viability were decided as this is an important stage. Members of the community are always engaged in needs assessment.

4.2. Sustainable Forest Management. The respondents from Saboti forest views on sustainable forest management were sought based on a scale 5 likert scale. A total of 13 items were used to explore the respondent's views on forest management, and results are presented in Table 2. The access to forest resources was fair $(M=3.78 ; \mathrm{SD}=1.17)$, local community feels secure $(M=3.91 ; \mathrm{SD}=1.12)$, and mechanisms for sharing benefits $(M=3.80 ; \mathrm{SD}=1.28)$. The respondents agreed on forest-dependent people $(M=3.80 ; \mathrm{SD}=1.31)$ and wages and other benefits $(M=3.96 ; \mathrm{SD}=1.13)$.

The respondents agreed that the number of people who use forest resources is balanced $(M=4.00 ; \mathrm{SD}=1.13)$ and children are educated about natural resource management $(M=4.01 ; \mathrm{SD}=1.05)$. Majority of respondents agreed that destruction of forest was rare $(M=4.11$; $\mathrm{SD}=1.02$ ) and people maintain spiritual links to the forest $(M=4.15 ; \mathrm{SD}=0.93)$. Majority of the respondents agreed that ecologically sensitive areas were protected $(M=4.35$; $\mathrm{SD}=0.72)$, ecological sites were protected $(M=4.25$; $\mathrm{SD}=0.86)$, erosion was minimized $(M=4.30 ; \mathrm{SD}=0.91)$, and there was significant quality of water $(M=3.89$; $\mathrm{SD}=1.34)$. From the thirteen statements used to explain, sustainable forest management had an overall mean of $M=4.02$; $\mathrm{SD}=0.79$. This implies that community members agreed with sustainable forest management in Saboti forest.

During the interviews, one of the forest officers stated that "Meetings are held during the initiation stage of a project or management plan development. All members are invited by KFS. The community gives ideas which are deliberated upon in order to come to an agreement of what are the most preferred ideas to be incorporated in the plan. The community identifies the gaps and intervention required in a participatory manner. The community also assists in giving baseline information for planning purposes. The community baraza meeting is indeed the most preferred mode of project meetings. We normally hold meetings on need basis, especially when we are starting new project."

The need to increase the number of people using forest services and to educate children (officially and informally) on natural resource use and degradation by local communities has been poorly understood by majority of the community members on sustainable forest management. Spiritual connections to nature are preserved, environmentally sensitive areas have been safeguarded, especially buffer areas along waterways, ecologically important sites are protected and managed accordingly, and deforestation and other types of soil degradation are reduced to a minimum. Exposure to forest services is seen to be equal socially, with local citizens feeling secure in terms of access to resources, and reward distribution systems are seen by local populations as fair.

In order for sustainable forest management to be realized, the community within which the resource is found must value it. These findings agree with the fact [2] that community benefits from the forest resource enable them to appreciate that resource and use it sustainably. Engagement of community will ensure sustainability in the management of the resource. The finding agreed with that of Mahanty, Guernier, and Yasmi [39] that not only emphasizes financial benefits but also encourages value-added research, market chain analysis, alternative forest products, and improved governance in general. This finding is consistent with forest management. Finally, in agreement with the work of Iversen, Chhetry, Francis, Gurung, Kafle, Pain, and Seeley [40], good maintenance of the forests also encourages nonconsumptive practices such as recreation, picnic, botanical gardens, religious, traditional shrines, and campsites. 
TABle 1: Participatory project initiation.

\begin{tabular}{llc}
\hline & Mean & Std. deviation \\
\hline There is public participation during needs assessment & 4.09 & 1.23 \\
Management objectives clearly described & 4.29 & 0.92 \\
Objectives are clearly stated & 4.23 & 0.96 \\
Committee members are a representation of local diversity & 3.88 \\
The contribution of all stakeholders is mutually respected & 4.21 \\
Management recognizes legitimate interests of stakeholders & 3.95 \\
Baseline studies are conducted with consultation during development of plan & $\mathbf{4 . 1 2}$ \\
Mean & 1.00 \\
\hline
\end{tabular}

TABLE 2: Sustainable forest management.

\begin{tabular}{lcc}
\hline & Mean & Std. dev \\
\hline Access to forest resources is fair & 3.78 & 1.17 \\
Local people feel secure & 3.91 & 3.80 \\
Mechanisms for sharing benefits & 3.80 & 1.12 \\
People receive employment & 3.96 & 1.28 \\
Wages conform to national standards & 4.00 & 1.31 \\
Balance people with forest resources & 4.11 & 1.13 \\
Children are educated on natural resource & 4.15 & 1.13 \\
Destruction of forest is rare & 4.35 \\
People uphold spiritual links with the forest & 4.25 \\
Ecologically sensitive areas are protected & 4.30 \\
Sites of ecological importance are protected & 3.89 & 1.05 \\
Erosion and other forms of soil degradation are minimized & $\mathbf{4 . 0 2}$ \\
There is quality supply of water & 0.93 \\
Mean & 0.72 \\
\hline
\end{tabular}

TABLE 3: Pearson's correlation results.

\begin{tabular}{lcc}
\hline & & Sustainable forest management \\
\hline Sustainable & Pearson's correlation & 1 \\
Forest management & Sig. (2-tailed) & $0.700^{* *}$ \\
& Pearson's correlation & 0.000 \\
Participatory project initiation & Sig. (2-tailed) & 0.000 \\
& Sig. (2-tailed) & 1 \\
\hline
\end{tabular}

${ }^{* *}$ Correlation is significant at the 0.01 level (2-tailed). Listwise $N=294$.

4.3. Correlation Results. Pearson's correlation was carried out, and results of the correlations are presented in Table 3. Findings of the study indicated that there was a significant influence of participatory project initiation on sustainable forest management $(r=0.700, p=0.00)$. This implies that an increase in participatory project initiation improved the sustainable forest management in Saboti.

This implies more participatory project initiation; there was an increase in sustainable forest management. It concurs with Mulwa [41] that community participation in need for evaluation provides a solid foundation for finding ways of solving the problem. This agrees with Meredith and Mantel [42] who describes the importance of various stages of the project initiation process in the accomplishment of a project.

\section{Conclusions}

The committee members are a representation of local diversity, and the contribution of all stakeholders is mutually respected. The management recognized the legitimate interests and rights of other stakeholders, and baseline studies are conducted with consultation during development of Participatory Forest management Plan (PFMP). The study concluded that participatory project initiation had significant influence on sustainable forest management. Community participation during the initiation stage was very important and significant.

\section{Recommendation}

There is need for forest management to involve the community members during the initiation stage of the projects in order to achieve sustainable forest management.

\section{Data Availability}

The data used to support the findings of the study are available upon request to the corresponding author. 


\section{Conflicts of Interest}

The authors declare that there are no conflicts of interest.

\section{Acknowledgments}

The research was self-funded by the principal author.

\section{References}

[1] World Bank, "Strategic environmental assessment of the Kenya forest act 2005: The world bank agricultural and rural department," Report No. 40659-KE, The International Bank for Reconstruction and Development, Washington, USA, 2007.

[2] L. Isager, I. Theilade, and L. Thomson, "People's participation in forest conservation: considerations and case studies," in Proceedings of the Southeast Asian Moving Workshop on Conservation, Management and Utilization of Forest Genetic Resources Forestry Research Support Programme for Asia and the Pacific (FORSPA), Thailand, February 2001.

[3] S. Tadesse, M. Woldetsadik, and F. Senbeta, "Forest users' level of participation in a participatory forest management program in southwestern Ethiopia," Forest Science and Technology, vol. 13, no. 4, pp. 164-173, 2017.

[4] L. Tacconi, "Decentralization, forests and livelihoods: theory and narrative," Global Environmental Change, vol. 17, no. 3-4, pp. 338-348, 2007.

[5] J. Newig and O. Fritsch, "Environmental governance: participatory, multi-level - and effective?" Environmental Policy and Governance, vol. 19, no. 3, pp. 197-214, 2009.

[6] L. I. Chirenje, R. A. Giliba, and E. B. Musamba, "Local communities' participation in decision-making processes through planning and budgeting in African countries," Chinese Journal of Population Resources and Environment, vol. 11, no. 1, pp. 10-16, 2013.

[7] F. Mulwa, Managing Community-Based Development: Unmasking the Mastery of Participatory Development, Premese Olivex Publishers, Nairobi, Kenya, 2004.

[8] I. E. Adesida and J. Okunlola, "Effects of community participation on the sustainability of rural infrastructure in ondo state, Nigeria," Asian Journal of Agricultural Extension, Economics \& Sociology, vol. 7, no. 1, pp. 1-9, 2015.

[9] F. Dolisca, D. R. Carter, J. M. McDaniel, D. A. Shannon, and C. M. Jolly, "Factors influencing farmers' participation in forestry management programs: a case study from Haiti," Forest Ecology and Management, vol. 236, no. 2-3, pp. 324331, 2006.

[10] M. A. Salam, T. Noguchi, and M. Koike, "Factors influencing the sustained participation of farmers in participatory forestry: a case study in central Sal forests in Bangladesh," Journal of Environmental Management, vol. 74, no. 1, pp. 43-51, 2005.

[11] T. Getacher and A. Tafere, "Explaining the determinants of community-based management of forest: evidence from Alamata," Ethiopian Journal of Health Development, vol. 1, pp. 63-70, 2013.

[12] S. Iddi, "Community participation in forest management in the republic of Tanzania," Ministry of Natural Resources and Tourism of Tanzania, vol. 42, no. 2, pp. 1-12, 2010.

[13] J. Ribot, Democratic Decentralization of Natural Resources: Institutionalizing Popular Participation, World Resources Institute, Washington D C, USA, 2002.

[14] J. K. Musyoki, J. Mugwe, K. Mutundu, and M. Muchiri, "Factors influencing level of participation of community forest associations in management forests in Kenya," Journal of Sustainable Forestry, vol. 35, no. 3, pp. 205-216, 2016.

[15] E. Mwangi, J. Mogoi, P. Ongugo, E. Obonyo, and V. Oeba, "Communities, property rights and forest decentralization in Kenya: early lessons from participatory forestry management," Conservation and Society, vol. 10, no. 2, pp. 182-194, 2012.

[16] P. O. Ongugo, "Participatory forest management in Kenya: is there anything for the poor," in Proceedings of the International Conference on Poverty Reduction and Forests, Bangkok, Thailand, September 2007.

[17] Ongugo, "The effects of internal human conflicts on forest conservation and sustainable development in Kenya," in Proceedings of the International A Paper Presented in the IASC Conference, Cheltenham England, July 2008.

[18] FAO [Food and Agriculture Organization United Nations], Global Forest Resources Assessment. Progress Towards Sustainable Management of Forest, FAO, Rome, Italy, 2012.

[19] S. Kumar, "Does "participation" in common pool resource management help the poor? a social cost-benefit analysis of joint forest management in Jharkhand, India," World Development, vol. 30, no. 5, pp. 763-782, 2002.

[20] M. G. Reed, “Guess who's (not) coming for dinner: expanding the terms of public involvement in sustainable forest management," Scandinavian Journal of Forest Research, vol. 25, no. sup9, pp. 45-54, 2010.

[21] ACCORD, Natural Resources, the Environment and Conflict, The African Centre for the Constructive Resolution of Disputes (ACCORD), Durban, South Africa, 2009.

[22] C. K. Koech, P. O. Ongugo, M. T. E. Mbuvi, and J. O. Maua, "Community Forest Associations in Kenya: Challenges and Opportunities," Kenya Forestry Research Institute, Nairobi, Kenya, 2009.

[23] FAO, "Participatory forest management: a strategy for sustainable forest management in africa," in Proceedings of the International Workshop on Community Forestry in Africa, Banjul, The Gambia, April 1999.

[24] S. Warah, Participatory Management of Forests and Protected Areas: A Trainers' Manual, Bangkok: Regional Community Forestry Training Center for Asia and the Pacific (RECOFTC), Bangkok, Thailand, 2008.

[25] P. Matiku, M. Caleb, and O. Callistus, "The impact of participatory forest management on local community livelihoods in the arabuko-sokoke forest, Kenya," Conservation and Society, vol. 11, no. 2, p. 112, 2013.

[26] K. L. Maharjan, "Community participation in forest resource management in Nepal," Journal of Mountain Science, vol. 2, no. 1, pp. 32-41, 2005.

[27] S. Adhikari, T. Kingi, and S. Ganesh, "Incentives for community participation in the governance and management of common property resources: the case of community forest management in Nepal," Forest Policy and Economics, vol. 44, pp. 1-9, 2014.

[28] T. Degeti, Factors affecting People's Participation in Participatory Management of Forest: The Case of IFMP AdabaDodola in Bale Zone of Oromia Region MA Dissertation, Addis Ababa University, Addis Ababa, Ethiopia, 2003.

[29] E. Titus and I. Edet, "Level of community participation in the conservation of natural resources in Akamkpa government area, sourthern cross river state, Nigeria," Journal of Research and Method Education, vol. 4, no. 4, pp. 30-35, 2014.

[30] P. M. Guthiga, J. Mburu, and K. Holm-Mueller, "Factors influencing local communities' satisfaction levels with different forest management approaches of Kakamega forest, 
Kenya," Environmental Management, vol. 41, no. 5, pp. 696-706, 2008.

[31] D. E. Jacob and A. U. Ogogo, "Community participation in protected area management: a case study of cross river national park in forestry in the context of the millennium development goals," in Proceeding of the 34th Annual Conference of the Forestry Association of Nigeria held in Osogbo, pp. p412-415, Osun State, Nigeria, 2011 December.

[32] N. Maraga, K. Kibwage, O. Oindo, and O. Oyunge, "Community participation in the project cycle of afforestation projects in river Nyando basin, Kenya," International journal of current research, vol. 3, pp. 54-59, 2011.

[33] P. Ehigiator, Urban Slum Upgrading and Participatory Governance (PG): An Investigation into the Role of Slum Community-Based Institutions in Tackling the Challenges of Slums in Developing Nations the Case of Lagos State, Nigeria, 2013.

[34] S. Waisbord, "Family tree of theories, methodologies and strategies in development communication," Handbook of Communication for Development and Social Change, Sage, Thousand Oaks, CA, USA, 2001.

[35] J. K. Coetzee, Development: Theory, Policy and Practice, Oxford University Press, Oxford, England, 2001.

[36] S. N. V Kenya, The Story of Children Living and Working on the Streets of Nairobi, MX Publishing, London, United Kingdom, 2002.

[37] T. Yamane, Statistics: An Introductory Analysis, Harper \& Row, New York, NY, USA, 1973.

[38] J. R. Fraenkel and N. E. Wallen, How to Design and Evaluate Research in Education, McGraw, New York, NY, USA, 2000.

[39] S. Mahanty, J. Guernier, and Y. Yasmi, "A fair share? Sharing the benefits and costs of collaborative forest management," International Forestry Review, vol. 11, no. 2, pp. 268-280, 2009.

[40] V. Iversen, B. Chhetry, P. Francis et al., "High value forests, hidden economies and elite capture: evidence from forest user groups in Nepal's Terai," Ecological Economics, vol. 58, no. 1, pp. 93-107, 2006.

[41] F. Mulwa, Participatory Monitoring and Evaluation of Community Projects, Paulines Publications Africa, Nairobi, Kenya, 2008.

[42] J. R. Meredith and S. J. Mantel, Project Management: A Managerial Approach, Wiley, New York, NY, USA, 2006. 